\title{
Advertising, Solicitation and the Profession's Duty to Make Legal Counsel Available
}

In recent years there has been a growing awareness of the importance of access to the courts in a functioning democracy. ${ }^{1}$ As part of this trend, restrictions on advertising and solicitation by lawyers have come under serious attack. 2 To date, however, these restrictions have been eased only to a limited degree and for only a tiny percentage of the bar. ${ }^{3}$ This Note will argue that current prohibitions upon advertising and solicitation imposed by the organized bar constitute an indefensible curtailment of essential information which violates the First Amendment. It will propose a new Canon 2 to the Code of Professional Responsibility which removes nearly all restrictions and conforms to constitutional requirements. Finally, the likely impact of such a revision upon the structure of the legal profession will be explored.

\section{The Problem With Current Restrictions}

\section{A. The Rules Against Advertising and Solicitation}

Although commentators have tied prohibitions on advertising and solicitation ${ }^{4}$ to the historical animus against "stirring up litigation"

1. See, e.g., Boddie v. Connecticut, 401 U.S. 371 (1971) (access to courts may not be denied to indigents who cannot pay court fees and costs of a divorce); Griffin v. Illinois, 351 U.S. 12 (1956) (state may not use the requirement of a transcript bejond the means of the defendant to block access to appellate review). See also California IIotor Transport Co. v. Trucking Unlimited, 92 S. Ct. 609, 612 (1972) (the Sherman Act ennnot, consistent with First Amendment guarantees, be interpreted as prohibiting the use of courts to promote economic and business interests in the absence of sham). For a diseussion of the implications of Boddie see The Supreme Court, 1970 Term, 85 H.1kv. L. REv. 3, 101 (1971). See also Goodpaster, The Integration of Equal Protection, Due Process Standards and the Indigent's Right of Free Access to the Courts, 56 Iow L. REv. 293 (1970).

2. United Transp. Union v. State Bar of Michigan, 401 U.S. 576 (1971); United Mine Workers v. Illinois Bar Ass'n, 389 U.S. 217 (1967); Brotherhood of R.R. Trainmen v. Virginia ex rel. Virginia State Bar, 377 U.S. 1 (1964); NAACP v. Butcon, 371 US. 415 (1963).

3. See p. 1183 infra.

4. By the use of the term "advertising" this Note refers to activities which seck to inform, notify or persuade the public, but without the use of a person-to-person encounter. In contrast, "solicitation" refers to similar activities involving personal contact.

5. See P. Winfield, History of Conspiracy and Autse of Legal Procentre 142-4j (1921). For judicial comment, see, e.g., Holloway v. Lowe, 7 Port. 488 (Ala. 1838); In re Davidson, 64 Nev. 514, 186 P.2d 354 (1947); State v. Rubin, 201 Wis. 30, 229 N.W.' 36 (1990). It has been suggested that solicitation was condemned first and that "advertising... became subject to disapproval as principles of good taste and legal etiquette crystallized." Note, Advertising, Solicitation and Legal Elhics, 7 VAND. L. REv. 677 (1954). It is doubtful that the justifications now offered for the rules account for their origin. H. DRINKER, Legal EThics 212 (1953)[hereinafter cited as DrINkER]. 
and to the prevention of barratry, champerty, and maintenance, ${ }^{0}$ their strict form is of relatively recent origin. No such restrictions were enforced by American bar associations prior to 1887,7 and the more stringent prohibitions which form the basis of the current rules were not adopted until $1908 .^{8}$ Since 1969 , advertising and solicitation have been governed by Canon 2 of the Code of Professional Responsibility and the various "Ethical Considerations" and "Disciplinary Rulcs" thereunder. ${ }^{9}$ The Disciplinary Rules prohibit almost everything that might be labelled as advertising apart from such innocuous devices as office signs and telephone directory listings. ${ }^{10}$ Similarly, the recommen. dation of one's own professional employment or that of a partner or associate and the use of employees to acquire legal business are pro. hibited forms of solicitation. ${ }^{11}$ Only narrow exceptions have been

6. Black's defines "barratry" as the offense of frequently stirring up suits, H. BLACk, Black's LAw Dicrionary 190 (4th ed. 1951); "champerty" as an agrecment to divide the proceeds of litigation between the owner of the claim and a party supporting the liti. gation, id. at 292; and "maintenance" as maintaining, supporting or promoting the liti. gation of another, $i d$. at 1106 . See also J. Miller, Handiook of CRiminal Law 150 (1934); 2 E. Thornton, Atrorneys at Law $\$ \$ 379-99$ (1914). The tangled history of inain. tenance and champerty and their relation to "stirring up litigation" have been thoroughly explored by Radin, Maintenance by Champerty, 24 CALif. L. REv, 48 (1935) [hercinafter cited as Radin]. The attitude that litigation by its very nature was to be discouragcd did not appear in Greek or early Roman law, but derives from the influence of Cliristianity. Id. at 54, 56. For judicial comment, see, e.g., Backus v. Byron, 4 Mich. 535 (1857).

7. "The first Code of Professional Ethics in the United States was that formulated and adopted by the Alabama State Bar Association in $1887 \ldots$.. Drinker, supra note $b$,
at 23 .

8. Id. at 212-15.

9. ABA, Code of Professional Responsibilitx and Canons of Judicial Etinics bal4 (1970) [hereinafter cited as ABA CODE]. The ABA House of Delegates adopted the Final Draft on August 12, 1969 to become effective January 1, 1970. The relation between thic new Canon 2 and earlier prohibitions against advertising and solicitation is analyzcd by Smith, Canon 2: "A Lawyer Should Assist the Legal Profession in Fulfilling Its Duly to Make Legal Counsel Available," 48 TEx. L. Rev. 285, 290.96 (1970). Smith concludes that Canon 2 codifies the existing rules against advertising and solicitation as found both in the old canons, and in the opinions of the ethics committees. Id. at 290 .

The new Code has grudgingly recognized the Supreme Court decisions which permitted certain groups to carry on activities which had been banned as forbidden advertisiug and solicitation, but it does not acknowledge the implications of these decisions. Se'c pp. 1183,1186 , and note 78 infra.

10. DR 2-101, DR 2-102, in ABA CODE at 7-8. These strictures are justificd by coplous citations to former $\mathrm{ABA}$ canons, prior $\mathrm{ABA}$ opinions, and other material. Id. at $10 \cdot 14$. See, e.g., In re Connelly, 18 App. Div. 2d 466, 478, 240 N.Y.S.2d 126, 138 (1968) (110 justification for acquiescence in article which "plainly amounts to a self-interest [sic] and unethical presentation of his achievements and capabilities"); $A 13 i$ Opinion 313 (I964), American Bar Association, Opinions of the Commitree ON professional litilics 687 (1967) [hereinafter cited as ABA OrINIONS] (distinctive type in telephone directory prohibited); ABA Opinion 284 (1951), id. at 628 (claim of "specialty" in classificd listillg impermissible as an undue attempt to make name distinctive); $A B A$ Opinion 184 (1939), id. at 457 (laudation of legal ability in bad taste and ethically improper). This stumple is inadequate to convey the enormous concern of the organized bar with "imprope" advertising. For additional material, see DrINkER, supra note 5 , at 228.48 and sources
there cited.

11. DR 2-103, in ABA CODE at 8. Again, citations are offered. Id. at 14. Sec, c.g., State v. Dawson, 111 So. 2d 427, 431 (Fla. 1959) (direct solicitation as well as the use of runners and touters condemned); $A B A$ Canons of Professional Ethics Nos. 27 \& 28 (1967), 
grudgingly carved out for such organizations as legal aid services. ${ }^{12}$ In one form or another, these restrictions have been enforced by the American courts. ${ }^{13}$ Breaches of the rules may result in censure, suspension or disbarment either under the inherent power of the court to discipline its officers ${ }^{14}$ or under specific statutes. ${ }^{15}$ Although the District of Columbia Bar Association has recently taken the unprecedented step of allowing "public interest" law firms to advertise for clients and express legal opinions in publications and over the air, ${ }^{10}$ the rules have generally been interpreted strictly. ${ }^{17}$

Supporters of the current rules contend that a variety of undesirable consequences would flow from a general easing of the restrictions.

ABA OpINons, supra note 10, at 74-77, 130; ABA Opinion 307 (1962), id. at 673, 675 (seeking to perform legal "check-up" for non-client prohibitcd). For further citations, see Note, note $\overline{5}$ supra, at $683-90$, and sources cited; Comment, A Critical Aualysis of Rules Against Solicitation by Lawyers, 25 U. CHI. L. Rev. 674 passim (1958).

12. Canon 2 of the ABA CODE codifies this exception in DR 2-103(D). Although a lawyer may not personally advertise, he may cooperate with the following types of legal services which do advertise, "provided that his independent professional judgunent is exercised in behalf of his client without interference or control by any organization or other person": legal aid offices, bar association referral services, public defenders offices, military legal assistance offices, bar associations, and other non-profit organizations that recommend, furnish, or pay for legal services to their members, "but only" in those instances and to the extent that controlling constitutional interprctation at the time of the rendition of the services requires the allowance of such legal service activities ...."Id. at 8 (emphasis added).

Although DR 2-103(D) does not mention it, ABA opinjons have prolibited the inclusion of a specific lawyer's name in otherwise permissible legal services advertising. AB.A Opinion 227 (1941), ABA OrINions 520; AB.A Opinion 205 (1940), id. at 493; AB. Opinion 191 (1939), id. at 464. More recently, the same concern was cridenced by the Committee on Legal Ethics and Grievance of the Bar Association of the District of Columbia, In re Advertising Conducted by Monroe $H$. Freedman and the Stern Community Law Firm, March 8, 1971 (on file at the Yale Law School Libran). The use of an individual attomey in otherwise pernissible advertising was found "objectionable." Id. at 2. For a sampling of decisions dealing with legal service activities sec Gunnclls $v$ : Atlanta Bar Ass'n, 191 Ga. 366, 12 S.E.2d 602 (1940); In re Community Action for Legal Services, Inc., 26 App. Div. 2d 354, 274 N.Y.S.2d 779 (1966); 1B.1 Opinion I48 (1935). ABA OpINons 416. See generally Blakeslee, Legal Aid Offices and Advertising, 53 . 1.B.1. J. 1148 (1967); Roche, Ethical Problems Raised by the Neighborhood Law Olfiec, 11 Notre Dame Law. 961 (1966).

13. See, e.g., Ex parte Newton, 265 Ala. 650, 93 So. $2 d$ lot (19j0); In re Tribblc, $M$ Ariz. 131, 382 P.2d 237 (1963); Tonini v. State Bar of California, 40 Cal. 2d 491, 297 P.2d 1 (1956); Levine v. Comm. on Admissions \& Grievances, 328 F.2d 519 (D.C. Cir. 1964); In re Rothman, 12 N.J. 528, 97 A.2d 621 (1953). See generaily F. Hicks, OnGivizatioN AND ETHICS OF THE BENCH AND BAR 238 (1932).

14. See, e.g., Ex parte Wall, 107 U.S. 265, 288-90 (1883); Thomas v. Statc, 87 Ga. App. 765, 75 S.E.2d 193, 196 (1953); In re Greathouse, I89 Minn. 51, 58, 248 N.W. 735. 738 (1933).

15. See, e.g., Ala. Code tit. 46, \$ 44 (1958); MItcit. Costr. Laws \$ 750.167 (Supp. 1979); NEv. REv. STAT. $\$ 7.250$ (1965). For a compilation of the pre-1969 canons of the ABA with tables showing the jurisdictions in which each canon has becll adopted by statute, court rule, or by the state bar association sec G. BRAND, BAR Associstion, AtTorNers AND JUDGES (1956).

16. The District of Columbia Bar Association has determined that "a "public interest" law firm-one that represents the poor, minorities, consumers and environmental groups -may advertise for clients in publications and over the air." N.Y. Times, March 10, 1971, at 25, col. 6; Washington Post, March 10, 1971, at Al, col. 1 , at $\mathrm{AG}$, col. 2; noted in Public Interest Law Firms, D.C.B.J., Jan.-June 1971, at 8, 9.

17. The stringency of the current rules owes much to the strict interpretations of the A.B.A. Ethics Committee. See ABA Orivions, supra note 10, at 74-129. 
They argue that advertising and solicitation would lead to the assertion of fraudulent claims, ${ }^{18}$ the corruption of public officials, ${ }^{10}$ the stirring up of litigation, ${ }^{20}$ attacks on marital stability, ${ }^{21}$ and the unnecessary invalidation of transactions due to the discovery of lawyers' mistakes.22 Advertising and solicitation, it is said, would cncourage lawyers to engage in overreaching, ${ }^{23}$ overcharging, ${ }^{21}$ underrepresentation, ${ }^{25}$ and misrepresentation. ${ }^{20}$ Particular emphasis is placed on the role played by advertising and solicitation prohibitions in preserving the dignity of the legal profession. ${ }^{27}$ Commentators maintain that the public would lose confidence in lawyers, the law, and the courts if the bar were seen as merely another commercial enterprise. ${ }^{28}$ They also fear that the commercialization of the bar would weaten the professional milieu. ${ }^{20}$ Any diminution in the status and self-image of the lawyer, it is urged, would make it more difficult for lawyers to live up to the ethical demands of their roles. ${ }^{30}$ There is additional concern that the performance of the legal profession might be weakened by

18. See, e.g., Note, Ambulance Chasing, 30 N.Y.U.L. Rev. 182, 187.88 (1955).

19. See, e.g., In re Disbarment Proceedings, 321 Pa. 81, 184 A. 59, 66.07 (1936); Repart of the Commiltee of Censors to the Pliladelphia Bar Ass'n, 14 Mass. L.O. Sur1., Nov. 1928, at 1, 14.

20. See B. Christensen, Lawyers for Peolle of Moderate Meais: Some l'rouleais of Availability of Legal Services 142-46 (1970) [hereinafter cited as Curistensen].

21. The defendant "makes divorce cases a specialty. How many persons in our broad land weary of the chain that binds them. . . [W] [Wat better devices than thosc pratcticed by this defendant, could be contrived to increase these disquictudes, and stimulate to effort, by perjury, if need be, to free themselves from their supposed unliappy cont. dition? Is it desirable divorce cases should accumulate in our courts? If so, the defendant is justified in the means he has used, and is using to that end." l'cople ex rel. Moses $v$. Goodrich, 79 Ill. 148, 154 (1875). See, e.g., People v. MacCabc, 18 Colo. 186, 188.91, 32. 1'. 280, 281 (1893); State v. Crocker, 132 Neb. 214, 217-18, 271 N.W. 444, 446 (1937). I11 the past the courts have punished advertising for divorce litigation especially severely. Sec", e.g., In re Biaggi, 36 Cal. App. 650, 172 P. 1130 (1918) (suspension); l'cople ex rel. Deneen v. Smith, 200 Ill. 442, 66 N.E. 27 (1902) (disbarment); In r Cohen, 261 Mass. 484, 159 N.E. 495 (1928) (suspension); In re l'orep, 60 Nev. 393, 111 1'.2d 533 (1941). Sict generally 2 E. THORNTON, ATrORNeYS AT LAW $\$ 845$ (1914).

22. Cf. Backus v. Byron, 4 Mich. 535,551 (1857).

23. "Overreaching" refers to aggressive competition among lawyers for clients which leads to lawyers approaching clients at times when the clients are in 110 condition to properly consider retention of a lawyer, for example, immediately after an accident. Sict Note, Ambulance Chasing, 30 N.Y.U.L. REv. 182, 186 (1955) and cases cited thercill.

24. See id. at 185 .

25. See id.; Note, Settlement of Personal Injury Cases in the Chicago Area, 17 Nw. U.L. REV. 895, 899, 904 (1953).

26. See Chistensen, supra note 20, at 140-42.

27. See, e.g., Mayer v. State Bar, 2 Cal. 2d 71, 39 P.2d 206 (1934); Pcople v. MacCabe, 18 Colo. 186, 32 P. 280 (1893); In re Cohen, 261 Mass. 484, 159 N.E. 495 (1928); In 1e Greathouse, 189 Minn. 51, 248 N.W. 735 (1933); Ingersoll v. Coal Creck Coal Co., 117 Tenn. 263, 310-11, 98 S.W. 178, 190 (1906); $A B A$ Opinion 111 (1934); $\Lambda$ B.1 Orinions, supra note 10, at 364; DR 2-102(A), ABA CODE 7; DR 2-103(D), $\Lambda \mathrm{BA}$ Cove 8. Sce generally Bradway, Publicity for Lawyers, 8 FED. B.J. 24, 55-59 (1946).

28. See Christensen, supra note 20, at 151. This argument curiously fails to include opposition to the sale of legal services for money, surcly an aspect of "commercializationt."

29. See id. at 154; DRINKER, supra note 5, at 211.

30. See CuRISTENSEN, supra notc 20 , at 151 . 
the tendency of the public to choose attorneys on the basis of their advertising programs rather than their professional competence. ${ }^{31}$

\section{B. The Rules Against Advertising and Solicitation and the First Amendment ${ }^{32}$}

Even evaluated in isolation, the justifications summarized above are not particularly persuasive. ${ }^{33}$ But the most glaring defect of the current prohibitions is their infringement upon potential litigants' right of access to the courts. In a series of cases beginning with $N A A C P v$. Button, ${ }^{34}$ the Supreme Court has declared association for purposes of legal representation to be a basic First Amendment right which may not be curtailed in the absence of a compelling state interest. ${ }^{35}$ The appellants in Button had been arrested and convicted for soliciting plaintiffs for suits to desegregate local schools, in violation of Virginia laws prohibiting advertising and solicitation of legal business. Reversing, the Court declared:

We hold that the activities of the NAACP, its affiliates and legal staff, shown on this record are modes of expression and association protected by the First and Fourteenth Amendments which Virginia may not prohibit, under its power to regulate the legal profession .... [U]nder the conditions of modern government, litigation may well be the sole practicable avenue open to a minority to petition for redress of grievances. ${ }^{36}$

In subsequent cases, including one decided last year, the Court has made it clear that the right to engage in "collective activity undertaken to obtain meaningful access to the Courts" ${ }^{37}$ embraces all types of litigation, not only that within the political arena. ${ }^{38}$

31. State v. Nichols, 151 So. 2d 257, 268 (Fla. 1963).

32. It is clear that bar association restrictions on advertising and solicitation involve state action within the meaning of the Fourteenth Amendment. See Notc, Exclusions from Private Associations, 74 YaLe L.J. 1313, $1319-21$ (1965); Lewis, The Afeaning of State Action, 60 Colum. L. REv. 1083 (1960); cf. Developments in the Law-Judicial Control of Actions of Private Associations, 76 HARv. L. REv. 983, 1068.69 (1963). For a remarkably candid judicial comment on the interrelationship of the canons of ethics and state powcr, see In re Rothman, 12 N.J. 528, 535, 97 A.2d 621, 625 (1953): "They [the Canons] are as obligatory on him [an attorney] as if cast in statutory form, as indeed they are in large part in many states." For a slightly more subdued deference, sce Hunter v. Troup, 315 Ill. 293, 302, 146 N.E. 321, 324 (1925) (emphasis added). "The American Bar Association is not a legislative tribunal, and its canons of ethics are not of binding obligation and are not enforced as such by the courts, although they constitute a safe guide for profes. sional conduct in the cases to which they apply, and an attomey may be disciplinied by this court for not observing them."

33. See pp. 1188-90 infra.

34. 371 U.S. 415 (1963). See cases cited note 2 supra.

35. See 371 U.S. at 438,444 .

36. 371 U.S. at $428-30$.

37. See United Transp. Union v. State Bar of Michigan, 401 U.S. 576, 585 (1971).

38. Cases cited note 2 supra. 
The drafters of the current Code of Professional Responsibility, in an attempt to bring the traditional restrictions on advertising and solicitation within constitutional bounds, have noted the above Supreme Court decisions ${ }^{39}$ but have construed them narrowly as applying only to group association for the purposes of litigation. ${ }^{40}$ Such an interpretation, however, is implausible as well as unwisc. There is certainly no indication in prior opinions that the Court intended so restrictively to circumscribe the dissemination of information concerning access to legal representation. ${ }^{41}$ Indeed, the Court's primary emphasis has been not on the right of attorneys to advertise and solicit but rather on the importance of ensuring that those aggrieved receive information regarding their legal rights and the appropriate means of effectuating them, and this rationale would seem to pertain at least as much to aggrieved individuals as to groups. The concern with the right to receive information has been expressed in a number of Supreme Court decisions during the last thirty years protecting the dissemination of information about religious, ${ }^{42}$ social, ${ }^{43}$ and economic ${ }^{44}$ affairs. Viewed in such a context, advertising and solicitation con. ducted by private attorneys deserves, if anything, more protection than that by attorneys affiliated with organizations like the NAACP45 or the United Mine Workers. ${ }^{46}$ Potential clients who are so dispersed, disorganized, and powerless that they cannot organize their own litigation programs would seem to be in even greater need of information regarding their legal rights than those who at least possess the strength required to generate their own litigation activities.

Of course it does not follow from the fact that legal advertising and solicitation are within the scope of the First Amendment that they are absolutely protected. ${ }^{47}$ Nevertheless, Button makes it clear that cur-

39. See Canon 2, ABA CoDE, supra note 9, at 11 n.11, 14 n.123.

40. The extremely limited vision of the current Canon 2 on this particular matter is demonstrated by DR 2-103(D). See note 12 supra.

41. See United Transp. Union v. State Bar of Michigan, 401 U.S. 576, 585 (1971); United Mine Workers v. Illinois Bar Ass'n, 389 U.S. 217, 222-25 (1967); Brotherhood of

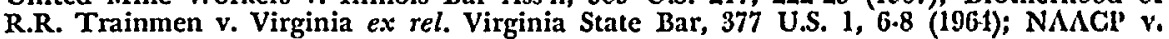
Button, 371 U.S. 415,429 (1963).

42. See, e.g., Marsh v. Alabama, 326 U.S. 501, 505 (1916) (right to receive Jehovali's WIt. nesses tracts); Martin v. City of Struthers, 319 U.S. 141, 143 (1943) (right to recclve Jehovah's Witnesses tracts).

43. See Griswold v. Connecticut, 381 U.S. 479, 482 (1965). See also Stanlcy v. Gcorgia, 394 U.S. 557, 564 (1969); Lamont v. Postmaster General, 381 U.S. 301, 305.07 (1965).

44. See Thomas v. Collins, 323 U.S. 516, 534 (1945) (right of workers to hear and be informed); Thornhill v. Alabama, 310 U.S. 88, 101.02 (1940) (right to reccive information communicated by labor picket signs).

45. See NAACP v. Button, 371 U.S. 415 (1963).

46. See United Mine Workers v. Illinois Bar Ass'n, 389 U.S. 217 (1967).

47. See, e.g., Konigsberg v. State Bar of California, 366 U.S. 36, 49 and n.10 (1961); Cantwell v. Connecticut, 310 U.S. 296, 307-08 (1940); Schneider v. State, 308 U.S. 147, 160.61 (1939). 
tailment of these activities can only be justified by a compelling state interest. ${ }^{48}$ Precise definition of "compelling" is, of course, elusive. But past judicial usage implies at a minimum that courts will subject advertising and solicitation restrictions to very close scrutiny and insist that there be no less drastic means available by which the state can achieve its objectives. ${ }^{40}$ Indeed, the Supreme Court followed this course in Button, Brotherhood of Railroad Trainmen v. Virginia ex rel. Virginia State Bar Association ${ }^{50}$ and Uniled Mine Workers v. Illinois Bar Association ${ }^{51}$ and found the states' justifications wanting.52 An examination of the traditional objections of fraud, overreaching, underrepresentation, stirring up litigation, and loss of dignity will demonstrate that they are no more compelling in the context of the current prohibition of advertising and solicitation by attorneys unaffiliated with organizations providing group legal services.53

It is mere conjecture and far from clear that fraud, overreaching, and underrepresentation would have a higher incidence in legal business procured by advertising and solicitation than in others. There is even less reason for concluding that advertising and solicitation by private attorneys pose a more serious threat than the group legal services activities protected by prior decisions. One might argue that there will be more overreaching and underrepresentation if lawyers are permitted to appeal directly to the public at large rather than only through associations which offer legal services to their members. But in at least one important aspect, advertising and solicitation by a private lawyer or law firm presents less danger than the activities involved in Button, Trainmen, and UMIW. A conflict between the lariyer's goals and the client's interests is not as likely to exist in litigation by individuals, because the lawyer is paid by and is responsible only

48. 371 U.S. at 438 .

49. See, e.g., United States v. Robel, 389 U.S. 258, 268 (1967); Sherbert v. Verner, 374 U.S. 398, 406-07 (1963); Shelton v. Tucker, 364 U.S. 479, 488 (1960); cf. Schncider v. Smith, 390 U.S. 17, 24 (1968); NAACP v. Button, 371 US. 4135,438 (1963). Sce also Wormuth \& Merkin, The Doctrine of Reasonable Allemative, 9 UTAII L. REv. 254, 207.93 (1961): Note, The Chilling Effect in Constitutional Law, 69 Colum. L. REv. 803 (1969); Note, The First Amendment Overbreadth Doctrine, 83 HARv. L. REv. 844 (1970).

50. 377 U.S. 1 (1964).

51. 389 U.S. $217(1967)$.

52. The Button Court concluded that "although the petitioner has amply shown that its activities fall within the First Amendment protections, the State has failed to advance any substantial regulatory interest, in the form of substantive evils flowing from petitioner's activities which can justify the broad prohibitions which it has imposed." 371 U.S. at 444.

53: The First Amendment status of legal advertising and solicitation is not limitcd by the fact that such activities possess a commercial component. Although Valentine $r$. Christensen held that the First Amendment does not protect "purely commercial advertising," 316 U.S. 52, 54 (1942), Times v. Sullivan rejected an attempt to apply this doctrine to advertising that communicated information of public interest and concern. 376 U.S. 254, 265.66 (1964). See note 58 infra. 
to his client rather than to the goals of an association. ${ }^{54}$ The strongest refutation of the contention that the current broad restrictions on advertising and solicitation serve a compelling state interest by prcventing the evils of fraud, overreaching, and underrepresentation, however, is the availability of alternatives less drastic than absolute pro. hibition, which "would combat such abuses without infringing First Amendment rights." "55 The assertion of fraudulent claims is prohibited by law quite independently of the ethical proscriptions against advertising and solicitation. ${ }^{56}$ "[T] $[\mathrm{T}$ laws of fraud, together with civil liability for any failure by a lawyer to perform as promised, would appear to offer substantial protection to the public against serious misstatcments or exaggerations." 57 To permit advertising and solicitation docs not mean that fraud, overreaching, and underrepresentation need be tolerated. The ethical canons could, consistent with the First Amendment, ${ }^{58}$ continue to proscribe these evils so long as the proscriptions are narrowly drawn. 50

One of the oldest complaints against advertising and solicitation is that they would "stir up" litigation. ${ }^{60}$ The medieval notion that litigation is evil per $\mathrm{se}^{61}$ has, however, been widely rejected, and it is now recognized that litigation often serves vital social functions. ${ }^{02}$ But

54. The relationships among the lawyer, the client and the sponsoring association have taken a slightly different form in each of the cases which have reached the Court. In Button the normal procedure was to help a potential litigant by furnishing a lawyer who was on the NAACP staff, 371 U.S. at 420 . In Trainmen, the litigant was directed by union officials to union approved lawyers, who were paid by the clients, 377 U.S. at .4. In United Mine Workers there was a lawyer on the union payroll who handled claims for personal injury and death for union members and their dependents, $389 \mathrm{U.S}$. at 219. 111 United Transportation the union not only recommended union legal counsel to its metil. bers, but had an agreement with counsel that legal fees would not exced twenty-five per cent of the recovery, 401 U.S. at 578 .

55. Sherbert v. Verner, 374 U.S. 398, 407 (1963).

56. See Christensen, supra note 20, at 141-42.

57. Id. at 141 .

58. The prohibition of deceptive advertising ordinarily has been held not to offend the provisions of the First Amendment. See, e.g., Donaldson v. Read Magazinc, Inc., 333 U.S. 178, 189.92 (1948); Regina Corp. v. FTC, 322 F.2d 765, 770 (3d Cir. 1963); Murray Space Shoc Corp. v. FTC, 304 F.2d 270, 272 (2d Cir. 1962). But see the stringent standard of proof required in New York Times Co. v. Sullivan, 376 U.S. at 268. For a discussion of the constitutional issues which the regulation of deceptive advertising raises sec Develop. ments in the Law-Deceptive Advertising, 80 HARv. L. REv. 1005, 1029.34 (1967) and cilses cited therein.

59. Of course the constitutional validity of all forms of state action that are instituted by bar associations as well as those that are contained in the criminal law must be judged by a single standard. This raises doubts concerning the wisdom of the bar's superviston of conduct which in most cases is already subject to criminal and civil restrictions.

60. Note 5 supra.

61. See Radin, supra note 6 , at 56.

62. Professor Radin has commented:

We must also disregard, I think, the assumption of medieval society, that a law suit is an evil in itself. It is hard to see how either the legal profession or our court machinery can justify its existence, if we go on the assumption that it is always better to suffer a wrong than to redress it by litigation. A law suit is an evil if it is bascless, 
a more modern version of the medieval idea still lurks about, which holds that courts ought to exist only for those sufficiently aggrieved to pursue their remedies independent of any outside influence. ${ }^{.3}$ The result of such a view is that the wealthy, knowledgeable and aggressive are favored ${ }^{64}$ over the poor, ignorant and timid. Indeed one suspects that an unvoiced reason for the animus against stirring up litigation is the fear that some of the litigation stirred up will involve socially unpopular causes-such as suits attacking segregation or those brought by tenants against landlords or consumers against corporations. ${ }^{\circ 5} \mathrm{But}$ this justification is constitutionally untenable, ${ }^{60}$ and if the restrictions depend upon it, they must fail. Of course it could be argued that advertising and solicitation would lead to frivolous suits. ${ }^{07}$ Surely, however, this evil can be dealt with short of prohibiting all advertising and solicitation. Indeed, lawyers are currently forbidden from engaging in frivolous suits quite independently of the advertising and solicitation restrictions. ${ }^{68}$ More importantly, the time and expense involved in litigation in the American courts seem sufficient to discourage the casual instigation of frivolous isuits.

The final and 'most amorphous argument offered in favor of the current restrictions is that they are necessary to preserve the dignity of the legal profession. To the extent that the concern with dignity merely represents the fears of some that advertising and solicitation would lower the self-image of the lawyer, it clearly cannot be permitted

or so uncertain that no one of common sense would wish to maintain it. If it is well-founded, if a wrong has been done or an obligation unfulfilled, if the wrongdoer will not of his own accord give proper reparation, a law suil ought to be considered proper and commendable. If we have so little confidence in the process of law as to think otherwise, we shall do well to consider seriously a fundamental overhauling of our system.

Id. at 72; C. Black, The Peorle and tine Court, ch. 4 (1960): Shapiro, Judicial Mfodesty, Political Reality, and the Preferred Posilion, 47 Connel. L.Q. 175, 196-203 (1961); Zimroth, Group Legal Services and the Constitution, 76 YALE L.J. 966, 979 (1967); Comment, Controlling Lawyers by Bar Associations and Courts, 5 HaRv. Civ. Ricirts-Civ. Lid. L. REV. 301, 357 (1970).

During the New Deal era, the American Bar Association praised a group of attornejs who founded an organization called the Liberty League, whose purpose it vis to advertise and solicit suits against the National Labor Relations Board. Sce A.B.A. Opinion 148 (1935), ABA Orlsioss, supra note 10, at 416. Surely, in this case at least the $A B A$ committee felt that litigation was capable of serving a uscful function.

63. See Radin, supra note 6 , at 77 .

64. See Christensen, supra note 20, at 143 .

65. Cf. "The Appellate Division's rules on group representation secm to hase been motivated largely by a fear that poverty law firms wolild take cases with controversial political, social and economic issues" (footnote omitted). Botcin, The Constitutionality of Restrictions on Poverty Law Firms: 4 New York Case Study, 16 X.Y.U.L. REv. 748, 757 (1971).

66. A rule whose only function is to chill the exercise of constitutional rights is patently unconstitutional. United States v. Jackson, 390 U.S. 570, 581 (1968).

67. See Christensen, supra note 20, at 142 .

68. See ABA CoDE, supra note 9, EC 2-30, DR 2-109. 
to limit First Amendment rights. To the extent it is feared that advertising and solicitation would diminish the public's confidence in the legal profession and ultimately its effectiveness, the concern is more serious but probably without foundation. Why in a nation where advertising is considered proper for nearly all types of businessmen arc bar leaders so certain that advertising by lawyers would degrade the profession in the eyes of the lay public? The engineering profession, for example, allows advertising ${ }^{60}$ and has done so for many years ${ }^{70}$ but nonetheless occupies a high place in terms of prestige and public confidence. Similarly banks, though they advertised little until the 1930's, now employ extensive advertising. ${ }^{11}$ They do not seem to have suffered any diminution in status or public trust. ${ }^{72}$ Indeed it is difficult to discern any connection between advertising and loss of prestige. " $[R]$ espect for law and legal processes is determined chiefly by how well these processes operate to resolve individual's problems."73 The important reasons for public disenchantment with lawyers and the law cannot be subsumed under the rubric "commercialization" but are rather "delay, undue bother, excessive cost, and outright injustice." 74 The efficiency impact of the increased competition which advertising and solicitation might generate, discussed below, might wcll increase rather than decrease the effectiveness of the legal profession in fulfilling society's needs. ${ }^{75}$

There is no easy answer to the fear that the public might choose attorneys on the basis of their advertising programs rather than their reputations for professional ability. It would of course be better if clients chose their lawyers on the basis of competence. But to comparc that happy situation with the one which would result if advertising were allowed is misleading, because it is not at all clear that clients cur-

69. See National Sociery of Professional ENgineers, Code of Ermics $\$ 3$ (195.1). The advertisements may not be "sclf-laudatory" or likely to discredit or unfavorably te. flece on the profession. Other professions have rules prohibiting advertising and soliciti. tion similar to those of the legal profession. See Americin Dental Association, l'kinci-

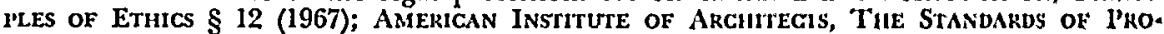

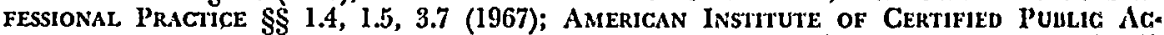
countants, Code of Professional Etuics art. 3 (1965), reprinted in J. CakeY \& W. Donerty, Ethical Standards of the Accounting Profession 183 (1966); AMekican Mivtcal Association, l'rincil'les of Medical Ethics $\$ 5$ (1966).

70. See, e.g., AmErican Ass'N OF ENGINEERS (Proceedings at First National Confurchice on Public Information), PuBlicity METHODS FOR ENG1NEers (1922).

71. See, e.g., L. Hodges \& R. TIllman, Bank MARkeing: Text AND Cases (1968);

W.O. Ross, MARKeting in CoMmercial BANKS: How to Proceed (1968).

72. See Citristensen, supra note 20, at 151; Missouri BAR-Prentice Hale Sunvey, $\Lambda$ Motivational Study of Public Arritudes and Law Office Management 60.61 (1963)

[hereinafter cited as Mo. BAR Survey].

73. See Christensen, supra note 20, at 153 .

74. Id.

75. See pp. 1206.08 infra. 
rently select lawyers on the basis of competence, or that they could do so in the absence of information which is blocked by the prevailing restrictions on advertising and solicitation. Non-deceptive advertising would at least increase this flow of information. ${ }^{70}$ This discussion is not intended to suggest that the loosening of restrictions on advertising and solicitation will have little or no impact. As the final section of this Note argues, advertising and solicitation are likely to have a significant long range effect, probably beneficial, on the structure and functioning of the legal profession. Neither is it contended that all the policy objectives of the current restrictions are constitutionally impermissible, but only that the nearly absolute prohibition of advertising and solicitation represents an overbroad method of preventing the evils of underrepresentation, overreaching, and frivolous suits. As the Button court declared, "because First Amendment freedoms need breathing space to survive, government may regulate in this area only with narrow specificity." 7 This the current rules have conspicuously failed to do.

\section{A Proposed Solution: A New Canon 2}

\section{A. The Approach to Re-Drafting}

To remedy the unconstitutional overbreadth of the present prohibitions against advertising and solicitation, a less drastic alternative to the current Canon 2 is necessary. The proposal which follows eliminates most prohibitions and allows the market to regulate the content and form of most advertising and soliciting. It provides for regulation or prohibition of only those activities which can be reached by the state without infringing upon First Amendment protections.

To be consistent with the organizational scheme adopted throughout the present Code of Professional Responsibility, the proposed Canon 2 consists of three separate but interrelated parts: the Canon itself, which embodies the general concept; ${ }^{i 8}$ the Ethical Considerations, which state

76. Although some of the traditional justifications for the rules against advertising and solicitation have not been explicitly discussed they are covered by the textual dis: cussion. See p. 1184 supra. The fear of attacks on marital stability and the unnecessary invalidation of transactions due to the discovery of lawyers' mistakes is merely another version of the animus against stirring up litigation, and there are less drastic and more effective means of preventing the corruption of public officials than prohibiting legal ad. vertising and solicitation.

77. NAACP v. Button, 371 U.S. 415, 433 (1963).

78. ABA CODE, supra note 9, at 1 . Canon 2 seems to make a significant advance orer the old canons dealing with advertising and solicitation when it sets out a positive duty for lawyers to educate laymen. EC 2-2 "The legal profession should assist lajmen to reeognize legal problems because such problems may not be self-revealing and often are 
the "objectives toward which every member of the bar should strive";" and the Disciplinary Rules, which set out "the minimum level of conduct below which no lawyer can fall without being subject to disciplinary action." 80 The format and language of the present Canon 2 have been retained wherever possible. ${ }^{81}$

\section{B. The Result: $A$ New Canon 2}

\section{CANON 2}

\section{A Lawyer Should Assist the Legal Profession in Fulfilling its Duty to Make Legal Counsel Avallable}

\section{ETHICAL CONSIDERATIONS}

EC 2-1. The need of members of the public for legal services is met only if they recognize their legal problems, appreciate the importance of seeking assistance, and are able to obtain the services of acceptable legal counsel. Hence, important functions of the legal profession are to educate laymen to recognize their problems, to facilitate the process of intelligent selection of lawyers, and to assist in making legal services fully available.

Comment. This introduction from the current Canon 2 is retained because it forthrightly states goals for the legal profession which admirably comport with the public's right to receive information about their legal rights and about the legal services available to them. The current Canon 2, however, proceeds from this promising beginning to emasculate its enunciated goals.

not timely noticed." See p. 1193 infra. But the only substantive change the new Canon 2 has made over the old canons is to add one more category to the legal services activities a lawyer may cooperate with. In addition to the previously accepted legal ald office, public defenders office, military legal assistance office, bar association referril serv: ice, and bar association, the lawyer is now permitted to cooperate with other non-profit organizations that recommend, furnish, or pay for legal services for their beneficiaries, but only to the extent that current constitutional interpretation requires the allow'ance' of such legal services activities. DR 2-103(D), id. at 8. A more grudging acknowledgment of Button, Trainmen, and $U M W$ could not have been devised.

79. Id. at 1 .

80. Id.

81. To facilitate comparison between the proposed and the current Canon 2, changes are indicated in the following manner. A series of asterisks indicates where material has been deleted, and an accompanying footnote either reproduces or summarizes the words deleted. Material which has no counterpart in the current Canon 2 is italicized. Wherc the deletion or addition of material has affected the numbering of the Ethical Considerations (EC) or Disciplinary Rules (DR) this is indicated by a footnote which gives the analogous section in the current Canon 2. If there is no footnote, the numbering of the EC or DR in the proposed Canon 2 remains unchanged from the current Canon 2. Finally, where further explanation is deemed useful, a comment and/or illustration accompanies the proposed text. 


\section{Recognition of Legal Problems}

EC 2-2. The legal profession should assist laymen to recognize legal problems because such problems may not be sclf-revealing and often are not timely noticed. Therefore, lawyers * *82 should encourage and participate in educational and public relations programs concerning our legal system with particular reference to legal problems that frequently arise. $* * * 83$

Comment. The current EC limits permissible "educational and public relations programs" to notably ineffective ABA institutional advertising ${ }^{84}$ and programs which are not motivated by a desire to obtain employment. The proposed EC makes no such limitation because it recognizes that programs motivated by the lawyer's desire for profit and employment are likely to be the most successful and efficient in conveying useful information to the public.

**85

EG 2-3. A lawyer who writes or speaks for the purpose of educating members of the public to recognize their legal problems should carefully refrain from giving or appearing to give a general solution applicable to all apparently similar individual problems, since slight changes in fact situations may require a material variation in the applicable advice; otherwise, the public may be misled and misadvised. Talks and writings by lawyers for laymen should caution them not to attempt to solve individual problems upon the basis of the information contained therein. ${ }^{80}$

82. "[A]cting under proper auspices," AB.1 CoDE 5. These words are deleted becausc the current Canon 2 goes on to define proper auspices in a manner incousistent with this Note's basic premise that there is nothing wrong with secking emplojment by means of publicity programs.

83. "Such educational programs should be motivated by a desire to benefit the public rather than to obtain publicity or employment for particular lawjers. Examples of per. missible activities include preparation of institutional adiertisements and professional articles for lay publications and participation in seminars, Iectures, and civic programs. But a lawyer who participates in such activities should shun personal publicity:" Id.

84. "Institutional" advertising consists of publicity carricd on by the Ameriean Bar Association and local bar associations. According to ABA Opinion 179 (1938). AB.1 OpINIONs, supra note 10, at 449, institutional adsertising is permissible "provided that (I) no reference to individual lawyers is made, (2) the motivation is to benelit the lay public rather than to increase professional employment, and (3) the manner in which it is presented is in keeping with the dignity and tradition of the profession." See, $1 \mathrm{~B}_{1} 1$ Opinion 121 (1934), id. at 376; ABA Opinion 191 (1939), id. at 464; IB.1 Opinion 227 (1941), id. at 520. Lawyers are understandably reluctant to contribute to bar association public relations programs in which the name of their firm does not appear and their particular credentials are not advertised. See Telser, Advertising and Competition, 72 J. [or. Ecos. 537, 540 (1964).

85. The current EC $2-3$ and 2-4, ABA CODE 5, are deletcd entircly in the proposed Canon 2. They are based on the assumption that all advice to seek legal services is suspect if volunteered; these provisions establish the motivation of the lawjer-volunteer as being the relevant standard to sort out ethical from uncthical behavior. The omitted provisions prohibit lawyers from volunteering advice in the hope of employment.

86. This is the present EC $2-5$ in its entirety. Id. 


\section{Selection of a Lawyer ***87}

EC 2-4. Formerly a potential client usually knew the reputations of local lawyers for competency and integrity and therefore could select a practitioner in whom he had confidence. This traditional selection process worked well because it was initiated by the client and the choice was an informed one. ${ }^{88}$

EC 2-5. Changed conditions, however, have seriously restricted the effectiveness of the traditional selection process. Often the reputations of lawyers are not sufficiently known to enable lay. men to make intelligent choices. The law has become increasingly complex and specialized. Few lawyers are willing and competent to deal with every kind of legal matter, and many laymen have difficulty in determining the competence of lawyers to render different types of legal services. The selection of legal counsel is particularly difficult for transients, persons moving into new areas, persons of limited education or means, and others who have little or no contact with lawyers. ${ }^{80}$

EC 2-6. Selection of a lawyer by a layman often is the result of the advice and recommendation of third parties-relatives, friends, acquaintances, business associates, or other lawyers. A layman is best served if the recommendation is disinterested and informed. ${ }^{.0}$ * * *1 In the event the third party making the recommendation is not disinterested, a layman is best served if full disclosure of the third-party's interest is made. Therefore, a lawyer should not compensate another person for recommending him/her, for influencing a prospective client to employ him/her, or to encourage future recommendations unless it is disclosed to the potential client that the person making the recommendation is compensated by the recommended lawyer. Whenever a solicitation is mude: without the prior knowledge of the recommended lawyer, and a "gratuity" is later paid to the third-party, disclostre of that fact should be made by the lawyer to the potential client.

Comment. The analogous section in the current Canon, EC 2.8, flatly forbids a lawyer to pay compensation to another person for recommending his or her services. But such a prohibition denies the

87. The proposed Canon 2 telescopes into one heading Ethical Considerations which appear under two headings in the current Canon: Selection of a Lawyer: Generally and Selection of a Lawyer: Professional Notices and Listings. Id. Permitting gencral advertising and solicitation will leave the current detailed treatment of law lists an anachronisill, therefore this portion of the existing Canon is deleted.

88. EC 2-6 in the current Canon $2, i d$.

89. EC 2-7 in the current Canon 2, $i d$.

90. The analogous section in the current Canon 2 is EC 2-8, but the deletions and additions have altered the substance. $I d$.

91. "In order that the recommendation be disinterested, a lawyer should not seek to influence another to recommend his employment. A lawyer should not compensate an. other person for recommending him, for influencing a prospective client to cmploy hilit, or to encourage future recommendations." $I d$. 
potential client an important source of information. The proposed language protects this source of information and at the same time protects the potential client by requiring full disclosure of the thirdparty's interest. Thus, the potential client is in a position to discount the proffered recommendation to whatever extent is felt necessary.

EC 2-7.92 $A$ lawyer has the right to engage in advertising and solicitation to aid in securing professional employment. The methods of advertising and solicitation in which lawyers engage should not deceive the public. * * *03 The attorney-client relationship is personal and unique and should not be established as the result of pressures and deceptions. ${ }^{92} * * 05$

Comment. This Ethical Consideration is the heart of the proposed Canon 2. It permits a free flow of information which will be useful to potential clients, but also recognizes a state's right to prohibit deceptive advertising and soliciting. It is important to note that neither EC 2-6 nor EC 2-7, nor their enforcing Disciplinary Rules as set out below, prohibit the advertisement of legal fees. This information would be subject to the same restrictions as other types of information which might be advertised, i.e., it cannot be untrue or deceptive. Since the present Code of Professional Responsibility admits of a broad range of rather vague criteria which may permissibly affect the computation of legal fees and prohibits only "unreasonable" fees, ${ }^{06}$ the possibility of deceptive advertising deserves careful attention. However, concern over possible deception should not cloud the probable beneficial effects of advertising legal fees: important information would thereby be conveyed to the potential client, and price competition would probably drive down the price of many legal services. ${ }^{97}$ Canon 5 of the current Code of Professional Responsibility should be adequate to deter lawyers from reducing price to such an extent that the quality of legal services would suffer. ${ }^{98}$

92. There is no analogous section in the current Canon 2.

93. At this point in the current Canon 2 appears the subtitle: Selection of a Laumer: Professional Notices and Listings. See note 87 supra. All of current EC 2.9 and EC 2.10 are deleted from the proposed Canon 2 save the sentence inmediately following this footnote signal in the text. The current EC $2-9$ sets forth the traditional reasons justifying a ban on advertising and EC 2-10 lists certain permitted exceptions, such as telephone listings, letterheads, and professional cards, ABA CODE $\mathbf{5}$.

94. EC 2-9. $I d$.

95. EC 2-11, EC 2-12, and EC 2-13, id. at 5, 6, have been omitted because they do not deal directly with the issue under discussion. They would remain unchanged in the proposed new Canon 2 except for necessary renumbering.

96. EC 2-18, DR 2-106, id. at 6, 9.

97. See pp. 1206-08 infra.

98. ABA CODE 18-20, especially EC 5-1, id. at 18. 
EC 2-8. In some instances a lawyer confines his practice to a particular field of law. ${ }^{99}$ A lawyer may properly refer to such a limitation of practice. ***100

Comment. EC 2-14 of the current Canon 2 prohibits a lawyer from referring to himself or herself as a specialist, except where state controls exist to certify special competence. The proposed provision takes the view that such a broad restriction unnecessarily limits the dissemination of valuable information. The scope and complexity of the law today compel most lawyers to specialize, or at least to concentrate their practice, in limited areas of the law. Such specialization or concentration usually results in better service for the client, often at a lower price. ${ }^{101}$ The proposed provision seeks to make information regarding specialization available to potential clients. However, since deception may result from self-certification of expertise, a proposed Disciplinary Rule, DR 2-102, will set forth a three-tiered system for regulating information in this area.

The proposed Canon 2 would make no changes in the other Ethical Considerations in the current Canon, which deal with lawyer referral systems, ${ }^{102}$ providing legal aid services to people who cannot afford a reasonable fee, ${ }^{103}$ financial ability to employ counsel, ${ }^{104}$ and acceptance and retention of employment. ${ }^{105}$

\section{DISCIPLINARY RULES}

DR 2-101. Publicity in General.

(A) A lawyer shall not prepare, cause to be prepared, use, or participate in the use of any form of publicity or advertising which is untrue or deceptive. ***100

Comment. Consistent with the analysis presented above, ${ }^{107}$ lawyers will be subject to disciplinary action only for a very narrow range of

99. EC 2-14, id. at 6 .

100. "In the absence of state controls to insure the existence of special competence, : lawyer should not be permitted to hold himself out as a specialist or as having special training or ability, other than in the historically excepted fields of admiralty, trademark and patent law."Id. at 6. These words are deleted, since reference to a specialty would provide potentially useful information for laymen. See pp. 1200-01 infra.

101. See p. 1206 infra.

102. EC 2-15, ABA CODE 6.

103. EC 2-16, id.

104. EC 2-17 through EC 2-25, id.

105. EC $2-26$ through EC $2-32$, id. at 6,7 .

106. "[P]ublic communication that contains professionally self-laudatory statements calculated to attract lay clients ...." Id. at 7. "The current DR 2.101(B) specifies per. mitted "limited and dignified identification of a lawyer" under certain circuinstances, $i d$. It becomes irrelevant under the proposed scheme and is deleted.

107. See pp. 1186-91 supra. 
advertising and soliciting which is not protected by the First Amendment. Of course, the determination of what is or is not untrue or deceptive will often be difficult. Bar ethics committees and state courts will frequently have to decide when vagueness, ambiguity, exnggeration, or failure to disclose constitutes deception. In determining whether an advertisement is untrue, data, statistics, and expert testimony will often be in conflict. Fortunately, a body of law exists which should prove a useful guide in developing standards for legal advertising. Since 1914 the Federal Trade Commission has asserted jurisdiction over, and has ruled on, an extraordinarily wide range of deceptive advertising cases. ${ }^{108}$ The FTC opinions cannot be rotely applied, however, because legal advertising presents a special case in at least two ways. One of the FTC's most important insights is that what constitutes deception depends upon the area being regulated. This is particularly significant regarding legal advertising. Mis-statements which are overlooked or deemed unimportant in other advertising may be inappropriate in legal advertisements because the public lacks sophistication concerning legal services and may therefore be more easily deceived. Second, since the First Amendment protects the public's right to receive advertising which deals with legal rights and legal services to a greater extent than that promoting purely commercial products, ${ }^{100}$ bar ethics committees and state courts must carefully avoid causing a "chilling effect" upon legitimate legal advertising. Therefore the FTC standard of protecting the "ignorant, the unthinking and the credulous," 110 should probably be raised to protect the average or reasonable man. While this latter standard may result in more people being misled, it assures a greater flow of information to the public and better avoids infringement on First Amendment protections.

Illustrations. It is not within the scope of this Note to anticipate all the troublesome cases which might arise under this proposed Disciplinary Rule, but a few examples may serve to illustrate its dimensions.

"ABC Law Firm Has Won Eight Out of Ten Cases." An advertisement of this kind is a good example of how deception might be accomplished by the failure to disclose pertinent information. It presents an exactitude which deceptively masks a number of underlying questions. Did the firm take only the "best" cases? Were the doubtful cases

108. For a comprehensive discussion of the FTC and the standards it has developed, see Developments in the Law-Deceptive Advertising, 80 HARv. L. REv. 1005, 1019.27, 1038-63 (1967).

109. See notes 53 and 58 supra.

110. See Aronberg v. FTC, 132 F.2d 165, 167 (7th Cir. 1942); General Motors Corp. v. FTC, 114 F.2d 39, 36 (2d Cir. 1910), cert. denied, 312 U.S. 682 (1941). 
compromised or settled out of court, leaving an impressive ratio for cases taken to final judgment? Were the minor cases won but the major cases lost? The advertisement exudes an air of statistical certainty which is not meaningful when talking about a particular case and is likely to deceive a public which is relatively unsophisticated in the legal process. This and other types of selective releases of information should be subject to the closest scrutiny.

"All the Lawyers in ABC Law Firm are Graduates of Top Law Schools." Such an advertisement presents a close question which ultimately would turn on the particular composition of the ABC Law Firm. If indeed the $A B C$ lawyers had graduated from law schools which a reasonable man would consider "top," then the advertisement is not deceptive. To the extent a reasonable man and the advertiser would differ as to which law schools are "top," however, the advertisement is sufficiently ambiguous to cause deception. Where more specific information exists which is readily obtainable it should be used in the advertisement to avoid the possibility of deception. Individuals may disagree about the tastefulness of trumpeting certain specific facts, such as the law schools from which a firm draws its attorneys, but the proposed Canon 2 need not defer to particular notions of taste.

"The ABC Law Firm Will Help You Set Up A Trust for Your Children." The problem raised by this advertisement is that a layman might be persuaded to purchase legal services which he does not need or which are not suited to his particular income level. Another variant on this theme includes a layman who might be persuaded by advertising that he needs a lawyer's help in a situation he can actually handle without legal assistance. There can be no doubt that these are im. portant problems. However, they are more than adequately dealt with in Canon 5 which states that "A Lawyer Should Exercise Independent Professional Judgment on Behalf of a Client."111 There is no renson to attempt to indirectly regulate such abuses by prohibiting advertising. To do so would unnecessarily deprive the public of valuable information.

(B) Any advertising which presents a legal opinion shall clearly indicate that fact by prominent display of the words "in our opin. ion" or other words of similar effect.

Comment. This rule is another precaution designed to alert laymen to the uncertainty which necessarily exists in legal practice. Although

111. Canon 5, ABA CodE 18. 
the advertisement contains the legal opinion of the author(s), other legal opinions may also be held, and in the absence of a specific warning laymen may ascribe more authority to legal pronouncements than is justified. ${ }^{112}$

(C) A lawyer shall not compensate or give anything of value to representatives of the press, radio, television, or other communication medium in anticipation of or in return for professional publicity in a news item. ${ }^{13} \mathrm{~A}$ lawyer shall not compensate or give anything of value to any person or organization to recommend or secure his employment by a client, or as a reward for having made a recommendation resulting in his employment by a client ${ }^{114}$ unless it is disclosed to the potential client that the person making the recommendation receives compensation from the recommended lawyer.

Comment. This rule would support Ethical Consideration EC 2-6. The absolute prohibition against a lawyer compensating a representative of the mass media in anticipation of professional publicity in a news item is retained under the theory that laymen are unlikely to analyze news references to lawyers with the same degree of alertness and skepticism that they would exercise when evaluating normal commercial communications. In all other circumstances, disclosure of compensation is substituted for prohibition.

(D) A lawyer shall neither personally engage in, nor be a party to any deceitful or improper solicitation. Solicitation is clearly improper when a lawyer of ordinary prudence would be left with the conviction that the potential client who is being solicited is in such an emotional or mental stale that he cannot be expected to exercise reasonable judgment as to the retention of counsel.

Comment. Of course any untrue or deceptive statements are as improper in soliciting as they are in advertising, and standards which determine deceit in DR 2-101 (A) are equally applicable to solicitation. But, unlike advertising, solicitation involves direct and personal contact with the potential client. To protect against unscrupulous solicitation this proposed rule defines and prohibits "improper" solicitation, particularly in moments of physical or emotional stress.

112. The use of the warning words "in our opinion" was suggested by the Committee on Legal Ethics and Grievance of the District of Columbia Bar Association in its report on advertising conducted by Professor Monroe H. Freedman and The Stem Community Law Firm. In re Advertising Conducted by Aronroc $\mathrm{H}$. Freedman and the Stern Community Law Firm, March 8, 1971 (on file with Yale Law Librarj).

113. Current DR 2-101(C). The sentence is retained, unchanged.

114. This sentence comes from the current DR 2.103(B), ABA CODE 8. 
(E) A lawyer shall not enter into a binding contingent fee agreement without giving the potential client at least forty-eight hours in which to freely exercise a right of cancellation.

Comment. Proposed EG 2-7 provides in pertinent part that "[ $t]$ the attorney-client relationship . . . should not be established as a result of pressures." The proposed rule under consideration here is designed to avoid some of the difficulty of proving whether or not a particular attorney-client relationship has been established as a result of pressure. The rule focuses on the contingent fee contract as a practice which is susceptible to abuse, especially with respect to solicitation, and seeks to curtail potential abuses by providing for a forty-eight hour cooling off period, which gives the potential client the opportunity to reconsider his judgment. ${ }^{115}$

Illustration. Mr. Jones is involved in a two car automobile accident and as a result of injuries sustained is taken to a hospital. A lawyer from $A B C$ Law Firm gets word of the accident and immediately goes to the hospital and talks with Mr. Jones. Following their conversation the lawyer persuades Mr. Jones to sign a contingent fee contract with ABC Law Firm. This, of course, is the classic "ambulance chasing" case with which the legal profession has long been concerned. Proposed DR 2-101 (D) and (E) would protect Mr. Jones from this kind of abuse. If Mr. Jones is sufficiently recovered in forty-eight hours to take action, DR 2-101 (E) permits him to freely cancel the contingent fee contract. If, however, his condition is such that more than forty-eight hours passes before he is able to recover sufficiently to fully understand the nature of the agreement he has entered into, DR 2-101 (D) would give him adequate grounds to cancel his contract.

***116

DR 2-102. Area of Practice.117

(A) A lawyer who is certified as a specialist in a particular field of law or law practice by the authority having jurisdiction under state law over the subject or specialization by lawyers may hold

115. For a similar provision in state law, see N.Y. Pers. Prol. LAw art. (10)(a) (Mckill. ney Supp. 1971) which permits a person three days in which he may cancel any contract which has been brought to him by a door-to-door salesman.

116. DR 2-102 Professional Notices, Letterheads, Offices and Law Lists, has been omitted. ABA CODE 7,8 . $(A)$ and $(F)$ deal with permissible exceptions to the current batt on advertising and would be deleted as irrelevant. (B), (C) and (D) contain nothillg coll. flicting with a lifting of the current restrictions and could remain unchanged. (E) secks to prohibit a lawyer from public mention of the fact that he is also engaged in another business. It would be deleted.

117. The analogous current DR is 2-105 Limilation of Practice, id. at 9. The only part of it retained in the proposed new Canon 2 is DR 2.105(A)(4) retaincd as DR 2.102( $\Lambda)$. 
himself out as a specialist but only in accordance with the rules prescribed by that authority. 118

(B) A lawyer who states that his practice is limited to a specific area (or areas) of the law, must in fact limit his practice to that (those) areas.

(C) A lawyer who is not a certified specialist, and does not desire to confine his practice solely to certain staled areas of the law may still indicate preferred areas of practice. * *118

The remaining Disciplinary Rules in Canon 2 refer to fees, ${ }^{120}$ agreements restricting the practice of a lawyer, ${ }^{121}$ and acceptance of and withdrawal from employment, ${ }^{122}$ and would remain unchanged in the proposed Canon 2.

\section{Some Implications of a New Canon 2: A Forecast}

One cannot address the question of how the modification of the current rules prohibiting advertising and solicitation might affect the bar without noting the considerable differentiation ${ }^{123}$ within the legal services industry in terms of income and a wide range of other characteristics. ${ }^{124}$ In general, large law firms tend to have substantially all the major corporate clients in a particular area. ${ }^{125}$ Most of their lawyers come from Protestant ${ }^{126}$ and middle-class or professional families ${ }^{12 \pi}$

118. DR 2-105(A)(4), id.

119. DR 2-103 sharply limits a lawyer's quest for recommendations for professional employment, id. at 8. DR 2-103(B) is retained in the proposed Canon 2 in a changed format at proposed DR 2-101(C). DR 2-104 which generally prohibits a lav'yer in accepting professional employment resulting from his own advice, id. at 9, is climinated in the proposed Canon 2 altogether.

120. DR 2-106, DR 2-107, id.

121. DR 2-108, id.

122. DR 2-109, DR 2-110, id. at 9, 10 .

123. The term "differentiation" is used here to cover income, prestige and other variables which may occur in any group.

124. See generally Berle, Modern Legal Practice, 9 Excr. Soc. Scr. 340 (1933). Ste also, J. Handler, The Lawyer and His Community: Tue Practicing Bar in A Midple. Sized CITY (1967); Freund, The Legal Profession, 92 DAED.alus 659 (1963). Gifford has drawn the following picture of the bar in cities over 50,000: an inner circle which handles virtually all corporate business; a narrow fringe of successful plaintiffs lawyers; and an area of "outer darkness," composed of men who barely make a living and perform only low-level tasks. Gifford, The Placement and Apprenticeship of Law Sehool Graduales, I J. Legal ED. 403, 404 (1949).

125. Berle paints a bleak picture of this development. "The law firm became virtually an annex to some group of financial promoters, manipulators or industrialists; and such firms have dominated the organized profession, although they have contributed little of thought, less of philosophy, and nothing at all of responsibility or idealism." Berle, supra note 152 , at 341 . For the practice of the large metropolitan corporate firm, see E. Sistcer, THE WALL STREeT LAWYER (1964).

126. In his study of 207 Detroit area lawyers in 1960-100 solo practitioners and 107 medium-to-large-firm lawyers, Ladinsky found that "while Protestants, as expected, predominate among the firm lawyers, they are a distinct minority among the solo lawjers (thirty one per cent)." Ladinsky, The Impact of Social Backgrounds of Laujers on Law Practice and the Law, 16 J. LeGAL ED. 127, 131 (1963) [hercinafter citcd as Ladinsky]. 127. Id. at 130-31. 
and have attended four years of college and a "major" law school.128 The legal tasks they perform tend to be relatively demanding intellectually, their income and prestige are high, and they typically control the city bar association. ${ }^{120}$ At the other end of the spectrum is the solo practitioner. ${ }^{130}$ The majority of individual practitioners come from working or lower-middle-class backgrounds, and have gone to a municipal or night law school. ${ }^{131}$ Real estate closings, collections, divorce and personal injury cases constitute a large portion of their work. ${ }^{132}$ They may well have to supplement this income by other work in order to support their families. ${ }^{133}$ The solo practitioner is generally unable to become a member of one of the large firms, ${ }^{134}$ or to have an effective voice in the city bar association. ${ }^{135}$ Of course there are some lawyers who are not at either end of this spectrumsuch as lawyers in small to medium-sized firms or the occasional large city solo practitioners who are wealthy and successful. Nonetheless it is critical to keep the heterogeneity of the legal profession in mind, because the allowance of advertising and solicitation will have differing impacts on the various sub-groups within the bar.

\section{A. The Large Law Firms}

Current restrictions on advertising and solicitation are implicitly based on an assumed mode of selecting counsel in which a potential

128. Id. at 131. "In Chicago, New York, Boston, Philadelphia, Cleveland, San Francisco, and Los Angeles, for example, at least one out of four lawyers in firms with over 25 lawyers is a Harvard, Yale or Columbia Law School graduate (principally Harvard), atud almost all the others are graduates of the top local university law schools." J. CAkLIN, Lawyers on Their Own: A Study of Individual Practitioners in Cincaco 17 (1962) [hereinafter cited as LAWYERS ON THEIR OWN] (footnote oinitted).

129. LAwYeRs ON THEIR OWN, supra note 128, at 176.

130. In his study of Detroit lawyers, Ladinsky noted that "individual practitioners ate 'minority' lawyers-they more often come from working class and entreprencurial familics of minority religious and ethnic status." Ladinsky, supra note 126, at 130. See generally Lawyers on Their Own, supra note 128, "Although half the lawyers in Chicago, as iii practically all the other cities of the United States, are individual practitioners, thcy con. stitute something like a lower class of the metropolitan bar. The elite of the metropolitan bar is composed of lawyers in the larger firms." Id. at 17 (footnotc omitted).

131. See id. at 3-6.

132. See LAwyers on THEIr OwN, supra note 128, at 41-122. The problems of getting business are also discussed. Id. at $81-91,123-54$. For a more recent study by him, J. CAnLIN,

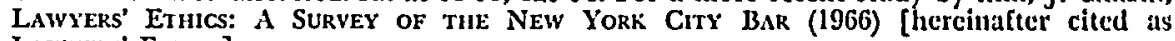
LAWYERS' ETHICS].

133. See Ladinsky, supra note 126 , at 135 .

134. "The rigidity of the class structure of the metropolitan bar is evidenced by the fact that those who start out as individual practitioners rarcly become associates or pitrt. ners in the larger law firms." L.swyers on TIIEJR OwN, supra note 128, at 18. Ste also LAWYERS' ETHICS, supra note 132, at 32.

135. Solo practitioners are often not even members of the principal professional asso. ciations, although they may be quite active in smaller, cthnic bar associations (in which there are few large firm lawyers). LAwYers on TiteIR OwN, supra note 128, at 175.8\%, This means, in particular, little control over advertising and solicitation rules. Id. at $177-84$. 
client knows the reputations of local lawyers for competence and integrity and acts accordingly. ${ }^{136}$ The potential clients of large law firms -major corporations and relatively wealthy individuals-probably come closest to the assumed level of knowledgeability. ${ }^{137}$ It follows that the repercussions of a modification of the rules regarding advertising will have a relatively insignificant impact on the large-firm lawyer. He would probably not find advertising especially advantageous, since the market he serves already has a relatively effective, if informal, mode of transmitting information regarding available legal services.

The experience in other industries tends to support this prediction. The industries which find advertising most important are those which produce inexpensive and frequently used ${ }^{138}$ consumer goods with mass markets.139 Products with lower frequency of purchase, higher cost, and a more sophisticated sort of purchaser make relatively less use of advertising and solicitation. This means that the relaxation of the legal advertising and solicitation prohibitions will probably not lead the large firms to hawk legal services, any more than banks advertise for commercial loans in that way. To the extent that current large firms do not offer inexpensive legal services to mass markets, one would expect them to be relatively undisturbed. ${ }^{140}$

Although it seems unlikely that the financial position or the prestige of the large-firm lawyer would be affected by changes in the rules restricting advertising and solicitation, he is nevertheless likely to oppose changes for several reasons. Large-firm lawyers are among the leaders of the bar and have been a guiding force for the rules that have developed.141 Certainly the present rules do not impede their practice,

136. EC 2-6, ABA CODE 5 .

137. See Mo. Bar Surver, supra note 72, at 35, 39-40; R. Rockwell, A Study of LaW axd the Poor in CaMbridge, Massachusetrs, ch. 4 (1968) [hereimafter cited as Rociwelt].

138. See J. Backman, Advertising and Competition 14-17 (1967): Drugs, cosmelic, soaps, soft-drinks and candies are the products which devote the largest percentage of gross sales to advertising. In 1965, over ten per cent of the sales revenue of these produets went toward advertising.

139. That is, within a given market a high percentage of the population uses the product.

140. It is unlikely that large firms would take advantage of advertising and solicitation to move into fields currently served by small firms and solo practitioners. First, large law firms are not subject to the same acute economic pressure that is squeczing many solo practitioners and small firm lawyers, so they are not as motivated to move into a new field. Second, the work of the solo practitioner or small firm lawyer is not likely to be coveted: it is probably more routine and clerical than the work performed by larger firms. See LAwYers on Their OwN, supra note 128, at 207. Carlin points out that cren under present conditions some of this work can be highly remunerative, but it is avoided by the large law firms because of its low prestige and a fecling that it is tainted with corruption and graft. Id. at 181-82. So although advertising and solicitation may presene opportunities for the economic advancement of some solo practitioners and stmall firm lawyers, its availability is not likely to induce larger firms to alter their type of practice.

141. Lawyers on Their Own, supra note 128, at 176. Shuchman, Elhies and the Legal Profession: The Propriety of the Canons as a Group Moral Code, 37 Gro. Wistl. L. REv. 241, 267 (1968) [hereinafter cited as Shuchman]. 
which involves business obtained in ways that are not currently proscribed.142 In addition, to the extent that the ban on advertising results in a failure on the part of some of the public to assert their legal rights, clients of established firms may benefit from the current rules. ${ }^{143}$ Finally, large-firm lawyers may have an emotional commitment to the present rules, considering them important to their self-imnge. ${ }^{144}$

\section{B. The Smaller Law Firms and Solo Practitioners}

\section{An Increase in Demand}

Lifting the restrictions on advertising and solicitation portends the greatest change among small firms and solo practitioners. There seems little doubt that a latent demand for legal services exists which would become actualized if the public were better informed. ${ }^{145}$ Not surprisingly, ignorance of the existence of rights and the benefits of representation tends to be greatest among the least well off and the lenst well educated.146 Attorney advertising can be expected to stimulate a substantial increase in demand for legal services from these groups, and one would expect the increase in legal business to flow to small

142. "Of course the [large firm lawyer] cannot solicit or advertise either. The canons in their 'majestic equality" forbid both the [large firm lawyer] and the [small firm lawyer] from overt solicitation in any form. But then, the [large firm lawyers] have no nced of such advertising. Their solicitation is more subtle, taking personal and fairly intimate social forms which usually cannot be the subject of ethical admonitions since the canons have not been violated, or proof is nearly impossible, or sanctions arc unavailing." Shuchman, supra note 141, at 256. "Firm lawyers do not need outside liaison men. Sclec. tive recruiting insures that the successful firm will include a number of men, ultimately prominent senior partners, who bring in the business" (footnotes omitted). Ladinsky, supra note 126, at 141 .

143. Shuchman, supra note 141 , at 267.

144. See p. 1184 supra.

145. See D. Caplovitz, The Poor Pay More, esp. ch. 12, (1967); Rockweld, supta note 137, esp. ch. 4 (1968); Mo. BAR SURveY, supra note 72, at 35; ABA Lawyer Referral Worls. shop Analyzes How to Meet Needs of Middle Class, March 12, 1971 (A.B.A. News Rclease). The Mo. Bar Survey found that 63 per cent of all Missouri citizens who could benefit from a lawyer's services either do not ever contact lawyers or fail to contact them on at least some occasions when they could be of assistance. Id. at 35, 39. It contends, further, that "[s]ome laymen do not appreciate the scope or limits of their problem, fail to see the potential danger, and thus fail to realize their need for legal advice." Id. at 136.

Carlin and Howard present evidence that tends to refute the contentions that: 1) the poor are less likely to use lawyers because they are less likely to need lawyers, and 2) though private counsel are unavailable for financial reasons, adequate substitutes for such representation are provided in the form of legal aid, court-appointed counscl, pub. lic defenders and special tribunals. Carlin \& Howard, Legal Representation and Class Justice, 12 U.C.L.A.L. REV. 381 (1965).

146. See Rockwerl, supra note 137 , ch. 4. Rockwell's study found that the percentage of those recognizing an appropriate situation as calling for a lawyer rose as income or cdi1. cation rose. Caplovitz has written that "knowledge of sources of help [in dealing with consumer fraud] increases sharply with formal education, and this overall pattern holds true for each racial group." CapLovirz, supra note 145 , at 176. 
firms and solo practitioners. Furthermore, many of the legal services which small firms and solo practitioners supply seem especially amenable to promotion through advertising-they are fairly inexpensive and have mass markets. These services include most aspects of conveying property, most aspects of mortgage lending, administration of decedents' estates, small debt collection, preparation of income tax returns for salaried persons, real estate tax contests, and complaints about government-administered programs such as social security and welfare. ${ }^{147}$ Finally, an allowance of advertising may enable some attorneys to compete more effectively with quasi-legal competitors. Although competition between lawyers and other service industries such as title insurance companies, accountants, trust departments, and realtors is lessened by restrictions against the unauthorized practice of law ${ }^{148}$ and treaties between bar associations and their various competitors, ${ }^{149}$ there are still many areas of law practice which overlap with these businesses. ${ }^{150}$ The Missouri Bar-Prentice Hall Survey revealed that one of the main reasons clients turn to these competitors for services is that many of the competitors advertise and/or solicit. ${ }^{161}$ This suggests that lawyers offering such services will have a reasonable opportunity to gain business if they are permitted to counter non-legal advertising with promotion of their orw..$^{152}$

\section{Lower Prices}

In addition to enabling lawyers to tap a demand for legal services which is currently inaccessible without advertising, relaxation of the restrictions on advertising can be expected to inaugurate price competition and push lawyers to undertake changes in the way legal services are performed. If a higher level of demand is realized, economies of scale now unavailable to small firms and solo practitioners may be-

147. This list is in part derived from Q. Jornstove \& D. Holsox, Lawrens and Tuen WORK 543 (1967).

148. See: American Bar foundation, Project on Unauthorized Practice of Law, Nos. 1 (1958), 2 (1961).

149. For copies of treaties with accountants, architects, banks with trust functions, casualty insurers, claims adjusters, collection agencies, life insurance companies, engineers, publishers, real estate title assurance, realtors, and social workers, sec MAntisp.iLEHUBBELl LAW DIRECTORY, 1972 at 323A (1972).

150. Mo. BAR SURYeY, supra note 72, at 130-38; Jolnstone \& Hoisos, supra note 147, chs. 5-10.

151. Mo. Bar SURvey, supra note 72, at 130-38.

152. The success of non-legal competitors has been due only partly to their skilled marketing. More efficient business organization has also played an important role. Advertising and solicitation will also provide a stimulus for lawjers to improve the cfficiency of the production of legal services. See pp. 1204.08. 
come feasible; these in turn promise a reduction in price and an expanded provision of legal services to the public at large.

At least since the publication of Dr. Alfred Z. Reed's Training for the Public Profession of the Law in 1921,153 and Present Day Law Schools in the United States and Canada in 1928,154 there has been widespread recognition that the legal profession could obtain cost economies through greater specialization and the use of para-profes. sionals. ${ }^{155}$ These potential efficiencies, however, have just begun to be exploited. Although specialization by lawyers is a commonplace in the large firm, ${ }^{156}$ the solo practitioner and most small firms have not achieved the efficiency which comes with specialization. ${ }^{167}$ Despite the encouragement given by the Code of Professional Responsibility, pariprofessionals ${ }^{158}$ have not been used, even by large firms, as extensively as they might be. ${ }^{150}$

Essential to the contention that advertising and solicitation will reduce prices for some legal services is the expectation that the legal services industry would become more competitive if the means for communicating essential consumer information were provided; this competitiveness would entail pressures such that cost economies would be passed along to consumers. Yet some have argued that advertising

153. A. Reed, Training for the Punlic Profession of the Law (Carnegic Foundation a Bull. No. 15 (1921)).

154. A. Reed, Present Day Law Schools in the United States and Canada (Carnegile Foundation Bull. No. 21 (1928)).

155. See generally Brickman, Expansion of the Lawyering Process Through a New Delivery System: The Emergence and State of Legal Paraprofessionals, 71 CoLUM. L. REV. 1153 (1971); Selinger, Functional Division of the American Legal Profession: An His. torical Prologue, 21 J. Legal Ed. 523 (1969); Sproul, Use of Lay Personnel in the Practice of Law: Mid-1969, 25 Bus. LAw 11 (1969).

156. Comm. on Specialization, Preliminary Report, 44 State B. Calif. J. 140 (1969). The principal specialties, in order of popularity were: 1) personal injury litlgation; 2) business and corporate law; 3) probate and estate planning; 4) divorce and family law; 5) real estate law; 6) criminal law.

157. In California, where solo practitioners and members of non-partnership assoclations make up only thirty-nine per cent of the bar, they include over half of the non. specialists. The majority of those in two-man firms are not specialists, but eighty per cent of those in firms above ten members do specialize. Not surprisingly, income is directly correlated to specialty practice. "Specialization by those making under $\$ 10,000$ is 44.1 per cent, while 79 per cent of those reporting income in excess of $\$ 50,000$ are specialists." "ll. at 145.

158. "A lawyer often delegates tasks to clerks, secretaries, and other lay persons, Such delegation is proper if the lawyer maintains a direct relationship with his client, stupervises the delegated work, and has complete professional responsibility for the work prod. uct. This delegation enables a lawyer to render legal service more economically and cfficiently." EC 3-6, ABA CODE at 15.

159. Helmeyer (Book Review, 55 Calif. L. Rev. 396, 399 n.24 (1967)) states that the ratio of non-legal staff to lawyers is about 1.5 to 1 . (Private study of fifty-four large law firms, thirty-one of which were New York firms.) As the ratio of secretaries to attorncys is fairly high, this leaves only a small ratio to other non-professionals, including messengers, file clerks, etc. Cf. Johnstone \& Horson, supra note 147, at 401. 
fosters concentration and market power, even in competitive and otherwise atomistic markets, in the long run. ${ }^{160}$

Assessment of the impact of advertising on the concentration characteristics of the legal services industry must for now remain speculative. ${ }^{161}$ It seems likely that an increased demand for legal services will generate structural changes, enlarging some firms, weeding out others, and fostering the emergence of new types of firms. ${ }^{102}$ Because firms tend to grow and change to take advantage of various economies of operation $^{\mathbf{1 6 3}}$ and because efficient use of para-professionals (to consider one prominent variety of potential economy) requires a relatively high volume of work, single practitioners and very small firms will have an incentive to expand. Firms may also find it profitable to undertake a wider range of services, enabling them to meet all of the legal needs of their clients, and this development would represent a

160. See J. Backman, Advertisinos and Competimion (1967).

The claimed anticompetitive effects of advertising may be summarized as follows:

1) The large company has the power of the large purse, which enables it to spend substantial sums on advertising, particularly to implement varying degrees of product differentiation which enables a company to pre-empt part of a markct.

2) Advertising thus creates a barrier to new firms entering an industry or a product market.

3) The result is high economic concentration.

4) Because of their protected position and because of product differentiation these firms can charge monopolistic prices which are too high. Moreover, they must recover the cost of the advertising by charging higher prices.

5) High prices in turn result in excessively large profits.

Id. at 4 .

161. Study of the economic implications of advertising is still in its infancy. Only a few statistical studies have been made of the existing data on advertising and they have not all yielded the same result. See, e.g., Mann, Henning \& Mechan, Advertising and Concentration: An Empirical Investigation, 16 J. IND. EcoN. 34 (1967) (advertising cxpenditures positively correlated with sellers' concentration); Telser, supra note 84 (advertising expenditures do not correlate with industry's concentration). See also Ekland \& Maurice, Comment: An Empirical Investigation of Advertising and Concentration, 18 J. IND. Ecos. 76 (1969). The books on the economics of advertising are primarily the summaries of the opinions of others. See J. Backiman, Advertisinc aNd Conmetrtion (1967); O. Firestone, The Economic Implications of Advertising (1967).

A further word of caution is in order. The economic studies which have been done by Telser and others deal mainly with industries which make physical products mather than with service industries such as law. Although advertising and solicitation are engaged in by some other professions (see W.O. Ross, MIARketinc IN Commercial BuNiks (1968); L. Hodges \& R. Tillaman, Bank Marketing: Text and Cases (1968); Americas Assoc. Of Engineers, Publicity Methods for ENGINefrs (1922)), no empirical studies have been done on the impact of advertising on the professions.

162. R.H. Coase discusses several answers to the question of why the economic entities called firms are formed and continue to exist in an article tiuled The Nature of the Firm, originally printed in Economica (1937), New Series, Vol. IV, 386-405, and reprinted in 6 AMERICAN EcoNoMIC Ass'N, ReAdincs IN PRICE TIEORY (Stigler \& Boulding eds. 1952) at 331 .

Coase's own answer is that a firm is formed to escape certain costs of using the price mechanism in the market. Id. at 336. The division of labor theory focuses on the increasing economic differentiation and the need of an integrating force. Id. at 344. Others look to the existence of uncertainty, reasoning that people are unhappy about having to forecast future wants, so a special class springs up who direct the activities of others to whom they will give guaranteed wages. Id. at 346 .

163. Id. at 339. 
cost-saving for the consumers of legal services. ${ }^{104}$ Medium to large size firms may also be generated because firms of this size may have an efficiency advantage in the utilization of manpower. Lawyers may be able to charge less per unit of time if their workload is steady, and this may result from a larger, more diversified firm structure.

If these hypothesized changes take place, the work currently done by very small firms and solo practitioners may to some extent be ab. sorbed by larger firms, though not the large corporate firms discussed earlier. ${ }^{165}$ This will involve an increase in concentration. But it must be remembered that the reason competition is a goal is that it promises to lead to more economical production and lower prices. It would be naive to embrace this goal and simultaneously object to concentration changes that reflect little more than the emergence of firms of efficient size. Though it has been contended that advertising enables producers to differentiate their products and thereby gain market power, ${ }^{106}$ it seems doubtful that legal services would be readily suscep. tible to differentiation of this sort. It remains true that a line exists in theory between growth of a firm to exploit scale economies and growth which yields only market power, with its attendant evils of oligopoly or monopoly profits, though this line is notoriously difficult to draw. For now, both the atomistic structure of the legal services industry, particularly within those portions of it which provide the services most amenable to promotion through advertising and solicitation, and the virtual absence of information as fostered by the restrictions imposed on lawyers, commend relaxation of the proscriptions in the manner suggested by the proposed revision of Canon 2 .

\section{Conclusion}

Although advertising and solicitation will doubtless create some abuses and offend some attorneys' sense of propriety, the existing prohibitions seem plainly unconstitutional. In addition to not furthering any compelling state interest, the restrictions seem to run directly against important concerns. The potential benefits of effectively educating people to their legal rights and fostering economic changes in the delivery of legal services which will bring those services within the reach of a larger proportion of the population seem large indeed. If the statement in Canon 2 of a professional obligation to make legal counsel available is to be honored, the present rules regarding advertising and solicitation must be modified.

164. Id. at 336 .

165. See p. 1203 and note 140 supra.

166. See note 160 supra. 